\title{
25(OH)D Inadequacy Has Different Pathway with VEGF in Increases the Risk of Severe Preeclampsia
}

\author{
Hanifa Erlin Damayanti, Aditiawarman \\ Department of Obstetrics and Gynecology, Faculty of Medicine, \\ Airlangga University, Dr Soetomo Hospital, Surabaya
}

\begin{abstract}
ABSTRAK
Tujuan: Mengidentifikasi hubungan secara in vivo antara 25(OH)D dengan VEGF dalam kejadian preeklampsia berat.

Bahan dan Metode: Penelitian ini merupakan sebuah penelitian analitik cross-sectional terhadap 36 wanita hamil, yang terdiri dari 18 pasien preeklampsia berat dan 18 pasien kontrol dengan usia kehamilan yang sesuai. Pemeriksaan kadar 25(OH)D serum dilakukan dengan chemiluminescent immunoassay (CLIA) dan pemeriksaan VEGF serum dengan sandwich ELISA terhadap semua pasien.

Hasil: Semua pasien sampel memiliki kadar 25(OH)D yang termasuk dalam kelompok insufisiensi dan defisiensi. Baik 25(OH)D dan VEGF serum berhubungan secara signifikan dengan kejadian preeklampsia berat dengan $\mathrm{P}$ masing-masing 0,012 dan 0,010 . Tidak didapatkan hubungan bermakna antara kadar 25(OH)D serum dengan VEGF serum $(\mathrm{P}=0,629)$.

Simpulan: Kadar 25(OH)D yang rendah berhubungan dengan peningkatan resiko terjadinya preeklampsia berat. Data yang ada tidak mendukung hipotesis mengenai VEGF mediator hubungan antara rendahnya kadar $25(\mathrm{OH}) \mathrm{D}$ serum dengan kejadian preeklampsia berat.
\end{abstract}

\begin{abstract}
Objectives: To identify in vivo correlation between $25(\mathrm{OH}) \mathrm{D}$ and VEGF in severe preeclampsia.

Materials and Methods: A case control, cross sectional study of 36 pregnant women which consist of 18 patients with preeclampsia and 18 patients as control with gestational age-matched. We perform 25(OH)D serum examination by chemiluminescent immunoassay (CLIA) and VEGF serum examination by sandwich ELISA to all patients.

Results: All patients are in $25(\mathrm{OH}) \mathrm{D}$ insufficiency and deficiency state. Both maternal 25(OH)D and VEGF levels were inversely associated with the risk of preeclampsia (both $\mathrm{P}<0.05$ ). There is no correlation between $25(\mathrm{OH}) \mathrm{D}$ serum level and VEGF serum level $(\mathrm{P}=0,629)$.

Conclusion: Maternal vitamin D deficiency is associated with increased preeclampsia risk. However, our data do not support the hypothesis that the association between vitamin D deficiency and preeclampsia is mediated by impaired level of VEGF.
\end{abstract}

Keywords: 25-hydroxyvitamin D, vascular endothelial growth factor, preeclampsia

Kata kunci: Vitamin D, 25-hydroxyvitamin D, vascular
endothelial growth factor, VEGF, preeklampsia berat

Correspondence: Hanifa Erlin Damayanti, Obstetric and Gynecology Department, Faculty of Medicine, Airlangga University, Dr. Soetomo Hospital, Surabaya, East Java, Indonesia. Phone: +62315501474, email : alin_baxx@ yahoo.com

\section{INTRODUCTION}

Preeclampsia is still a major cause of maternal morbidity and mortality in the world. Data from WHO on 2012 mention as many as $10 \%$ of all pregnancy are complicated with preeclampsia, with $5 \%$ of them need intensive care for eclampsia and severe preeclampsia complication. Almost $25 \%$ of babies born to preeclamptic mother are IUGR. ${ }^{1}$

Vitamin D has been known to have a major role in calcium metabolism, immune system, proliferation, differentiation of cells, infection, and cancer. ${ }^{2}$ In the last 10 years, vitamin $\mathrm{D}$ has been studied to determine its effect on conception, pregnancy and neonatal health. ${ }^{3}$ The maternal serum and umbilical cord level of $25(\mathrm{OH}) \mathrm{D}$ has been proven to penetrate the placenta and fully meet the fetal needs of vitamin D. ${ }^{4}$ Levels of $25(\mathrm{OH}) \mathrm{D}$ in the serum is directly related to the intake of vitamin D and sun exposure..$^{5}$ Low level of $25(\mathrm{OH}) \mathrm{D}$ in the first trimester of pregnancy is associated with the incidence of preeclampsia. ${ }^{6}$ Furthermore, vitamin D supplementation during the first year of life may reduce the risk of preeclampsia by $50 \%$ in the first pregnancy. ${ }^{7}$ Magnus (2001) examined the incidence of preeclampsia is associated with season. It was significantly lower in the summer with high sun exposure and calcidiol levels reached its peak. ${ }^{7}$

Vitamin D deficiency (levels of $25(\mathrm{OH}) \mathrm{D}<17.5 \mathrm{nmol} / \mathrm{L}$ ) and insufficiency (levels of $25(\mathrm{OH}) \mathrm{D}<50 \mathrm{nmol} / \mathrm{L}$ ) apparently were found in tropical countries with abundant sun exposure such as India and Bangladesh. Green (2008) examined the levels of 25(OH)D in women of reproductive age in Jakarta and Kuala Lumpur, showed $60 \%$ of them having insufficient levels of $25(\mathrm{OH}) \mathrm{D}$.Many studies tried to unravel the pathogenesis of preeclampsia associated with vitamin D deficiency, for example in the inflammatory response pathways, oxidative stress and angiogenesis. However, 
so far they have not obtained satisfactory results. One of the factors of angiogenesis is vascular endothelial growth factor (VEGF), considered able to be a predictor factor for preeclampsia and even a therapeutic agent for preeclampsia. Vitamin D is proven invitro to increase the activity of VEGF as specific mitogen and proliferation of blood vessels.Our study aims to investigate the relationship between 25(OH)D levels and serum VEGF in pregnancy with preeclampsia, by comparing it with low risk pregnancies. The results of this study are expected to provide an overview of how the role of $25(\mathrm{OH}) \mathrm{D}$ in the pathogenesis of preeclampsia, and how this relates to angiogenesis pathway.

\section{MATERIALS AND METHODS}

\section{Subjects}

Participating in this study were 36 pregnant women which consist of 18 patients with preeclampsia and 18 patients as control with gestational age-matched. Pregnant women were recruited consecutively into the study during their visit at the antenatal clinics and delivery room of Soetomo general hospital and Soewandhi general hospital between November 2014 and February 2015. Women with a history of any disease including chronic hypertension, obesity, diabetes, liver disease, kidney failure, autoimmune, twin pregnancy, and granulomatous diseases were excluded. Participants were interviewed and a data form was used to collect information about personal details, age, gestational age, prepregnancy weight, parity, education-al status, sun exposure duration, intake of food contains vitamin D, and sunblock usage. Informed consent was obtained and ethical approval was obtained from Ethical board.

\section{Serum 25(OH)D and VEGF measurement}

We perform 25(OH)D serum examination by chemiluminescent immunoassay (CLIA) and VEGF serum examination by sandwich ELISA to all patients. Cut-off values for $25(\mathrm{OH}) \mathrm{D}$ were as follows: deficiency (less than $10 \mathrm{ng} / \mathrm{mL}$ ), insufficiency (10 to $30 \mathrm{ng} / \mathrm{mL}$ ), and normal (more than $30 \mathrm{ng} / \mathrm{mL}$ ). Cut-off for VEGF values were not available. Statistical analysis was carried out using the IBM SPSS (Statistical Package for the Social Sciences) statistical software package version 20.0. Data were expressed as mean \pm standard deviation $(\mathrm{SD})$ or number and percentage of subjects. Correlations were performed using Spearman's test. Comparisons were conducted using unpaired Student's two-tailed t-test (Mann-Whitney as alternative). Chisquare tests (Fisher's test as alternative) were used to compare categorical variables. In all tests, the level of significance was $\mathrm{P}<0.05$.

\section{RESULTS AND DISCCUSION}

In total, 36 subjects enrolled with 18 subjects each in severe preeclapmsia and control group (Table 1). The mean age of these subjects was 28.1 (SD 6.57) years. There were one subject aged less than 18 years old and six subjects aged more than 35 years old. Prepregnancy BMI in severe preeclampsia and control group were 23.3 (SD 2.4) and 23.2 (SD 3.5), respectively. Most of the subjects are having their first pregnancy. The educational status were middle to high which means most of the subjects at least have finished their high school. We found no variables significantly influenced the incidence of preeclampsia. The $25(\mathrm{OH}) \mathrm{D}$ levels in severe preclapmsia and control group were 11.7 (SD 4.8) and 15.9 (SD 4.5) ng/mL, respectively. The VEGF levels in preclapmsia and control group were 13.3 (SD 3.1) and 17.5 (SD 5.5) $\mathrm{pg} / \mathrm{mL}$, respectively. Both maternal 25(OH)D and VEGF levels were inversely associated with the risk of preeclampsia (both $\mathrm{P}<0.05$ ).

Most of the subjects have $25(\mathrm{OH}) \mathrm{D}$ levels between 10 to $30 \mathrm{ng} / \mathrm{mL}$ (Table 2). Around $75 \%$ have insufficient levels of $25(\mathrm{OH}) \mathrm{D}$. There were no variables with the $\mathrm{P}$ values less than 0.005 . There were 20 out of 27 subjects $(74.1 \%)$ are at 28 weeks or more of gestational age having insufficient levels of $25(\mathrm{OH}) \mathrm{D}$ compared to $66.6 \%$ subjects in the deficiency levels of $25(\mathrm{OH}) \mathrm{D}$. Most of the subjects are exposed to sunlight more than 90 minutes per day. More than $75 \%$ subjects in each group taken at least twice per week of food that may contains high level of vitamin D.

The overall mean of 25(OH)D levels was 13.9 (SD 5.06) $\mathrm{ng} / \mathrm{mL}$. There were a significant association as shown (Table 3 ) between $25(\mathrm{OH}) \mathrm{D}$ levels and the incidence of preeclampsia with OR $13.6(\mathrm{P}=0.012,95 \% \mathrm{CI}$ 1.47 to 125.31$)$.

Overall mean of VEGF levels was 15,4 (SD 4,89) $\mathrm{pg} / \mathrm{mL}$. We also found a significant association between VEGF levels and the incidence of preeclampsia $(\mathrm{P}=$ $0.010)$. But correlation analysis found out that there is no correlation between $25(\mathrm{OH}) \mathrm{D}$ serum level and VEGF serum level $(\mathrm{P}=0,629)$. 
Table 1. Subjects' characteristics based on severe preeclampsia incidence

\begin{tabular}{|c|c|c|c|}
\hline \multirow{2}{*}{$\begin{array}{c}\text { Variables } \\
\mathrm{n}(\%)\end{array}$} & \multicolumn{2}{|c|}{ Group } & \multirow[b]{2}{*}{$\mathrm{P}$} \\
\hline & $\begin{array}{c}\text { Severe } \\
\text { preeclampsia }\end{array}$ & Control & \\
\hline Age, mean(SD) [year] & $29.2(6.9)$ & $26.9(6.3)$ & 0.305 \\
\hline \multicolumn{4}{|l|}{ Gestational age $(\mathrm{n}, \%)$} \\
\hline 24-33 weeks & $9(50.0)$ & $9(50.0)$ & \multirow{2}{*}{1.000} \\
\hline$\geq 34$ weeks & $9(50.0)$ & $9(50.0)$ & \\
\hline $\begin{array}{l}\text { Prepregnancy BMI, } \\
\text { mean(SD) }\end{array}$ & $23.3(2.4)$ & $23.2(3.5)$ & 0.957 \\
\hline \multicolumn{4}{|l|}{ Parity $(\mathrm{n}, \%)$} \\
\hline Primigravida & $11(61.1)$ & $10(55.6)$ & \multirow{2}{*}{0.735} \\
\hline Multigravida & $7(38.9)$ & $8(44.4)$ & \\
\hline \multicolumn{4}{|l|}{ Educational status (n,\%) } \\
\hline Low & $9(50.0)$ & $1(5.6)$ & \multirow{3}{*}{0.057} \\
\hline Middle & $5(27.8)$ & $14(77.8)$ & \\
\hline High & $4(22.2)$ & $3(16.7)$ & \\
\hline \multicolumn{4}{|l|}{ Working (n,\%) } \\
\hline Yes & $8(44.4)$ & $12(66.7)$ & \multirow{2}{*}{0.180} \\
\hline No & $10(55.6)$ & $6(33.3)$ & \\
\hline \multicolumn{4}{|l|}{ Hypertension history (n,\%) } \\
\hline Yes & $6(33.3)$ & $5(27.8)$ & \multirow{2}{*}{0.717} \\
\hline No & $11(66.7)$ & $13(72.2)$ & \\
\hline \multicolumn{4}{|l|}{ Diabetes history $(\mathrm{n}, \%)$} \\
\hline Yes & $1(5.6)$ & $5(27.8)$ & \multirow{2}{*}{0.177} \\
\hline No & $17(94.4)$ & $13(72.2)$ & \\
\hline $\begin{array}{l}25(\mathrm{OH}) \mathrm{D}, \operatorname{mean}(\mathrm{SD}) \\
{[\mathrm{ng} / \mathrm{mL}]}\end{array}$ & $11.7(4.8)$ & $15.9(4.5)$ & $0.012 *$ \\
\hline VEGF, mean(SD)[pg/mL] & $13.3(3.1)$ & $17.5(5.5)$ & $0.010^{*}$ \\
\hline
\end{tabular}

Table 2. Subjects' characteristics based on levels of 25(OH)D serum

\begin{tabular}{|c|c|c|c|}
\hline \multirow{2}{*}{$\begin{array}{l}\text { Variables } \\
\mathrm{n}(\%)\end{array}$} & \multicolumn{2}{|c|}{ Levels of $25(\mathrm{OH}) \mathrm{D}$ serum } & \multirow[b]{2}{*}{$\mathrm{P}$} \\
\hline & $\begin{array}{c}\text { Deficiency } \\
\mathrm{N}=9\end{array}$ & $\begin{array}{c}\text { Insufficiency } \\
\mathrm{N}=27 \\
\end{array}$ & \\
\hline Age, mean(SD) & $27.2(5.7)$ & $28,3(6.9)$ & \multirow[t]{2}{*}{0.657} \\
\hline Gestational age $(\mathrm{n}, \%)$ & $9(25.0)$ & $27(75.0)$ & \\
\hline 24\-28 weeks & $3(33.3)$ & $7(25.9)$ & \multirow{2}{*}{0.686} \\
\hline$>28$ weeks & $6(66.6)$ & $20(74.1)$ & \\
\hline $\begin{array}{l}\text { Prepregnancy BMI, } \\
\text { mean(SD) }\end{array}$ & $23,9(3.1)$ & $23,1(2.9)$ & 0.391 \\
\hline \multicolumn{4}{|l|}{ Parity $(\mathrm{n}, \%)$} \\
\hline $\begin{array}{l}\text { Primigravida } \\
\text { Multigravida }\end{array}$ & $\begin{array}{l}5(55.6) \\
4(44.4)\end{array}$ & $\begin{array}{l}16(59.3) \\
11(40.7)\end{array}$ & 1.000 \\
\hline \multicolumn{4}{|c|}{ Educational status $(\mathrm{n}, \%)$} \\
\hline Low & $4(44.4)$ & $6(22.2)$ & \multirow{3}{*}{0.893} \\
\hline Middle & $3(33.3)$ & $16(59.3)$ & \\
\hline High & $2(22.3)$ & $5(18.5)$ & \\
\hline \multicolumn{4}{|l|}{ Working $(\mathrm{n}, \%)$} \\
\hline Yes & $5(55.6)$ & $15(55.6)$ & \multirow{2}{*}{1.000} \\
\hline No & $4(44.4)$ & $12(44.4)$ & \\
\hline \multicolumn{4}{|c|}{ Hypertension hist. (n,\%) } \\
\hline Yes & $4(44.4)$ & $7(25.9)$ & \multirow{2}{*}{0.409} \\
\hline No & $5(55.6)$ & $20(74.1)$ & \\
\hline \multicolumn{4}{|l|}{ Diabetes history $(\mathrm{n}, \%)$} \\
\hline $\begin{array}{l}\text { Yes } \\
\text { No }\end{array}$ & $\begin{array}{l}1(11.1) \\
8(88.9)\end{array}$ & $\begin{array}{r}5(18.5) \\
22(81.5)\end{array}$ & \multirow[t]{2}{*}{1.000} \\
\hline Sun exposure(n,\%) & & & \\
\hline
\end{tabular}




\begin{tabular}{lrrr}
$<90 \mathrm{~min} /$ day & $2(22.2)$ & $4(14.8)$ & 0.627 \\
$\quad 90 \mathrm{~min} /$ day & $7(77.8)$ & $23(85.2)$ & \\
Vit D food intake (n,\%) & & & \\
$\quad$ Often & $5(55.6)$ & $15(55.6)$ & \\
$\quad$ Seldom & $2(22.2)$ & $12(44.4)$ & 0.893 \\
$\quad$ Never & $2(22.2)$ & $0(0.0)$ & \\
Long sleeves (n, \%) & & & \\
$\quad$ Yes & $3(33.3)$ & $9(33.3)$ & \multirow{2}{*}{1.000} \\
$\quad$ No & $6(66.7)$ & $18(66.7)$ & \\
Sunblock usage & & & \\
$\quad$ Yes & $2(22.2)$ & $3(11.1)$ & \multirow{2}{*}{0.581} \\
$\quad$ No & $7(77.8)$ & $24(88.9)$ & \\
\hline
\end{tabular}

Table 3. Association between incidence of severe preeclapmsia and 25(OH)D levels

\begin{tabular}{|c|c|c|c|c|c|c|}
\hline \multirow{2}{*}{$\begin{array}{c}25(\mathrm{OH}) \mathrm{D} \\
\text { levels }\end{array}$} & \multicolumn{2}{|c|}{ Group, n $(\%)$} & \multirow[b]{2}{*}{ OR } & \multirow[b]{2}{*}{$\mathrm{P}$} & \multicolumn{2}{|c|}{ CI } \\
\hline & $\begin{array}{c}\text { Severe } \\
\text { preeclampsia }\end{array}$ & Control & & & Lower & Upper \\
\hline Deficiency & $8(44.4)$ & $1(5.6)$ & \multirow{2}{*}{13.6} & \multirow{2}{*}{0.012} & \multirow{2}{*}{1.47} & \multirow{2}{*}{125.31} \\
\hline Insufficiency & $10(55.6)$ & $17(94.4)$ & & & & \\
\hline
\end{tabular}

Our study did not found any variables that related to the incidence of severe preeclampsia. Lechterman (2014) reported the same results which mentioned that mother's age, prepregnancy BMI, gestational age, and parity did not influenced the incidence of severe preeclampsia. Most of our subjects having severe preeclampsia are primigravida and low educational status. Opitasari (2014) reported similar findings that parity and educational status are factors influencing the incidence of severe preeclampsia. ${ }^{8}$

\section{Vitamin D deficiency and insufficiency}

The present study showed a high prevalence of vitamin $\mathrm{D}$ deficiency and insufficiency among pregnant women in Surabaya. About $25 \%$ have $25(\mathrm{OH}) \mathrm{D}$ levels lower than $10 \mathrm{ng} / \mathrm{mL}$ and $75 \%$ have $25(\mathrm{OH}) \mathrm{D}$ levels between 10 to $30 \mathrm{ng} / \mathrm{mL}$. None of them have normal $25(\mathrm{OH}) \mathrm{D}$ levels. There were no variables found out to be significantly influenced the incidence of deficiency or insufficiency of $25(\mathrm{OH}) \mathrm{D}$ levels. Other study reported by Lechterman at 2014 reported similiar results.

Vitamin D levels is influenced by adipose tissues. In obese, vitamin D was stored in the fat cells that causing a low 25(OH)D levels in serum. ${ }^{9}$ Therefore, in subjects with obese or overweight, the $25(\mathrm{OH}) \mathrm{D}$ levels are expected to dropped. ${ }^{10}$ In our study, there were no obese women since its already excluded in the recruit-ment, and $25 \%$ subjects are overweight. But there were no significant association between BMI and 25(OH)D levels in our study. This could be due to our small sample and no subject have normal 25(OH)D levels. Same results reported by $\mathrm{Li}$ (2011), who reported that
BMI was not associated with the levels of $25(\mathrm{OH}) \mathrm{D}$ serum in pregnancy.

Skin colour was not included in our study since most of our subject are Asians. De-Regil (2012) and Tsiaras (2011) reported that skin colour influenced the levels of vitamin D. They categorized the skin colour to AfricanAmerican, Caucasian, and Asian. ${ }^{10,11}$

Intake containing vitamin D especially in Asian, contributed to $25(\mathrm{OH}) \mathrm{D}$ serum levels. Even though it is not the main cause for vitamin D deficiency, some study reported it influced the vitamin D status. ${ }^{12}$ In our study, food intake was not significantly differs between vitamin $\mathrm{D}$ deficiency and insufficiency. This could be due to our data collection about the food intake did not considered food with vitamin $\mathrm{D}$ fortification or the concentration of vitamin D in those food. We only collected the information about how many times subject consumes food enriched with vitamin D.

\section{Levels of 25(OH)D serum and severe preeclampsia}

Our study revealed the $25(\mathrm{OH}) \mathrm{D}$ serum was between 4.5 to $26.8 \mathrm{ng} / \mathrm{mL}$. This findings are similar with other studies especially in Asian. Sachan (2005) reported in India $84 \%$ women with $25(\mathrm{OH}) \mathrm{D}$ serum levels lower than $22.5 \mathrm{ng} / \mathrm{mL}$. Cut-off values for $25(\mathrm{OH}) \mathrm{D}$ serum is different among studies. Sachan used the cut-off level for normal $25(\mathrm{OH}) \mathrm{D}$ is between 30 to $80 \mathrm{ng} / \mathrm{mL}$. While in Australia, the cut-off levels used are around 20 $\mathrm{ng} / \mathrm{mL}$. The low 25(OH)D levels in Asian women are 
suspected due to pigmentation and low intake of food containing vitamin D. ${ }^{12,13}$

Levels of $25(\mathrm{OH}) \mathrm{D}$ is the gold standard for evaluating vitamin $\mathrm{D}$ status. But since vitamin $\mathrm{D}$ metabolism in complicated, the levels of $25(\mathrm{OH}) \mathrm{D}$ will give different implication in every person. Therefore, it is suggested that to know the vitamin D status, other parameters such as parathyroid hormones are needed to checked also. Parathyroid hormones usually will be lower when 25(OH)D lower than $20 \mathrm{ng} / \mathrm{mL}^{14}$

There were a significant difference between preeclamptic mother and control regarding the $25(\mathrm{OH}) \mathrm{D}$ levels with $\mathrm{P}$ values lower than 0.05 . This findings are also supported by Xu (2014) with similar findings. Our study reported that the $25(\mathrm{OH}) \mathrm{D}$ levels in preeclampsia was $26 \%$ lower than in control group. This is greated than previous studies reported by $\mathrm{Xu}$ (2014) around $14 \%$ and Bodnar (2007) around 15\%. However, the mean levels of vitamin $\mathrm{D}$ in this study is lower than those studies. Mean of $21.76 \mathrm{ng} / \mathrm{mL}$ vs. $19.08 \mathrm{ng} / \mathrm{mL}$ at study $\mathrm{Xu}$ (2014) and mean of $22.8 \mathrm{ng} / \mathrm{mL}$ vs. $19.6 \mathrm{ng} / \mathrm{mL}$ at study Bodnar (2007). This is probably due to the sample of this study was obtained from a variety of gestational age with many different characteristics. Furthermore, our research sampling conducted from November 2014 to February 2015 in Surabaya, where rainfalls is very high every day. It is said that differences in levels of $25(\mathrm{OH}) \mathrm{D}$ between preeclampsia patients and controls obtained more significantly in the summer, when the levels of $25(\mathrm{OH}) \mathrm{D}$ in normal pregnancy increased, but remained lower in patients with preeclampsia. ${ }^{8}$

Recent studies have found that levels of $25(\mathrm{OH}) \mathrm{D}$ in early pregnancy is lower in women who eventually experienced preeclampsia. Decreased levels of $25(\mathrm{OH})$ $\mathrm{D}$ to $20 \mathrm{ng} / \mathrm{mL}$, gives a 2 -fold increased risk of the occurrence of preeclampsia. ${ }^{6}$ Research in Norway for 23,423 nulliparous women, found that vitamin D supplementation as 10-15 g/day is associated with a $27 \%$ reduction in the risk of preeclampsia compared with no supplementation $(\mathrm{OR}=0.73$, CI $0.58-0.92) .{ }^{15} \mathrm{In}$ this study, the odds ratio (OR) is 13.6. Since our study did not have any subjects with normal value of $25(\mathrm{OH}) \mathrm{D}$, we assumed that insufficiency were better than deficiency. With this OR, it means that the conditions of deficiency of $25(\mathrm{OH}) \mathrm{D}$ increase the risk of severe preeclampsia at 13.6 times compared insufficiency of $25(\mathrm{OH}) \mathrm{D}$.

\section{Levels of VEGF and severe preeclampsia}

In this study, serum VEGF levels associated with the incidence of severe preeclampsia $(P=0.010)$. These results are similar to results of a study by Wang (2009) which found a significant decrease in the levels of free VEGF and PIGF serum preeclamptic patients compared to normotensive patients and nonproteinuria using sandwich ELISA examination technique. VEGF is necessary to regulate blood pressure and maintain the integrity of the glomerular filtration barrier. The interaction of VEGF with its receptors is essential for the growth and function of the placenta, as well as stabilization of the maternal blood vessels. Decrease in the concentration of free VEGF in the serum of patients preeclampsia causes endothelial cell dysfunction maternal circulation. Polliotti et.al. showed that low VEGF levels are predictors of preeclampsia in the future. Levine et.al. found that levels of free VEGF in patients with preeclampsia found to be lower than normotensive women since 5 weeks prior to the occurrence of preeclampsia. ${ }^{16}$

In contrast, several studies such as Lyall (1997) and Oh (2001) found an increase in total circulating VEGF in serum of women with preeclampsia compared with normotensive women, as well as research by McKeeman (2004) and Shaarawy (2005). ${ }^{16}$ The discrepancy may occur due to the type of sandwich ELISA cannot detect the levels of VEGF total (bound and free) in serum. The study that found elevated levels of serum VEGF preeclampsia are using radioimmunoassay or ELISA system techniques that examine VEGF levels in total, unlike our study.

\section{Levels of 25(OH)D and levels of VEGF serum}

Our study found that levels of $25(\mathrm{OH}) \mathrm{D}$ serum in patients with preeclampsia and control is not associated with serum VEGF levels $(P=0.629)$, although both have a significant relationship with the occurrence of preeclampsia. This may be due to the number of samples is small (18 people for each group). Another possibility is that each of the $25(\mathrm{OH}) \mathrm{D}$ and VEGF have another pathophysiology in relation to the incidence of severe preeclampsia.

It has been known that there are several biological pathways for $25(\mathrm{OH}) \mathrm{D}$ in affecting the placenta, fetal, maternal health and pregnancy growth. Vitamin D has a role as an immunomodulator that is able to regulate the immune response to the mother's placenta, and is able to prevent infection during pregnancy. ${ }^{17}$ While in relation to preeclampsia, vitamin D deficiency predisposes proinflammatory response and increased oxidative stress which ended with endothelial dysfunction. Increased proinflammatory factors and oxidative stress may be an important factor in the pathophysiology of preeclampsia. Low levels of $25(\mathrm{OH}) \mathrm{D}$ are related to inflammatory vascular endothelial cells, increased NFkB signaling in suppressing vascular endothelial function, and reduced 
VDR on vascular endothelium and decreased expression of 1- $\alpha$ hydroxylase. In addition, cells expressing placental trophoblast 1a-hydroxylase (CYP27B1) and VDR in large numbers, so there is the hypothesis that vitamin D has an important anti-inflammatory role of the placenta.

Some studies also showed an increase in oxidative stress in subjects with deficiency of vitamin D. This increase can be reversed by vitamin D supplementation. ${ }^{18}$ In 2014, Wei conducted a study on the relationship of the levels of $25(\mathrm{OH}) \mathrm{D}$ with increased oxidative stress biomarkers and found that levels of 25(OH)D serum biomarkers associated with increased levels of F2isoprostanes $(5-\mathrm{iPF} 2 \mathrm{a}-\mathrm{VI})$ on gestational age 12 to 18 weeks $(\mathrm{r}=-0.261, \mathrm{P}=0.01)$ and 24 to 26 weeks $(\mathrm{r}=$ $0.246, \mathrm{P}=0.02$ ). After getting rid of confounding factors, it was found that levels of $25(\mathrm{OH}) \mathrm{D}$ less than $50 \mathrm{nmol} / \mathrm{L}$ at 24 to 26 weeks of gestation increased risk of preeclampsia (OR 4.20, 95\% CI 1.4 to 12.6). ${ }^{19}$

In this study, no relationship was found between decreased levels of $25(\mathrm{OH}) \mathrm{D}$ serum with decreased serum levels of VEGF. In this study, no assessment levels of pro-inflammatory factors and biomarkers of oxidative stress on the entire subject of research, so we can not evaluate whether inflammatory or oxidative stress factors that are more affected by reduced levels of $25(\mathrm{OH}) \mathrm{D}$ serum in the pathophysiology of preeclampsia.

Studies on the role of VEGF in preeclampsia find some mechanism reduction of VEGF. Several studies have reported increased levels of antiangiogenesis factors such as soluble fms-like tyrosine kinase (sFlt-1) is able to reduce levels of free VEGF to below the critical point needed for vasculogenesis and maintain vascularity which has been formed during pregnancy. ${ }^{16}$ sFlt-1 is expressed and secreted by several human tissues including endometrial, endothelial cells, and placental villus tissue. Several studies using primary cultures of isolation of human cytotrophoblast cells showed that low oxygen levels increased the expression of sFlt-1. sFlt-1 binds to VEGF with high affinity, resulting in lower levels of free VEGF. In normal pregnancy, levels of sFlt-1 will increase with gestational age, but the increase occurred more rapidly in serum and placental tissue of preeclampsia patients. Increased expression of sFlt- 1 obtained in vitro and in vivo models with sFlt-1 by hypoxia conditions still can not be explained by either. In this study, we did not examine antiangiogenesis factors such as sFlt-1, which may explain the decrease in VEGF in our study.

\section{CONCLUSION}

Maternal vitamin D deficiency is associated with increased preeclampsia risk. However, our data do not support the hypothesis that the association between vitamin D deficiency and preeclampsia is mediated by impaired level of VEGF, although there were significant differences of VEGF levels in preeclamptic mother to normotensive mother. Further research are needed to evaluate this phenomenon.

\section{REFERENCES}

1. Green TJ, Skeaff CM, Rockell JE, et al. Vitamin D status and its association with parathyroid hormone concentrations in women of child-bearing age living in Jakarta and Kuala Lumpur. European journal of clinical nutrition. 2008;62(3):373-8.

2. Garland CF, Garland FC, Gorham ED, et al. The role of vitamin $\mathrm{D}$ in cancer prevention. American journal of public health. 2006;96(2):252-61.

3. Holick MF. The Vitamin D Defi ciency Pandemic: a Forgotten Hormone Important for Health. Public Health Reviews. 2012;32:267-83.

4. Dror DK, Allen LH. Vitamin D inadequacy in pregnancy: biology, outcomes, and interventions. Nutrition reviews. 2010;68(8):465-77.

5. Hollis BW, Wagner CL. Vitamin D deficiency during pregnancy: an ongoing epidemic. Am J Clin Nutr. 2006;84:273.

6. Bodnar LM, Catov JM, Simhan HN, Holick MF, Powers RW, Roberts JM. Maternal vitamin D deficiency increases the risk of preeclampsia. The Journal of clinical endocrinology and metabolism. 2007;92(9):3517-22.

7. Hypponen E, Turner S, Cumberland P, Power C, Gibb I. Serum 25-hydroxyvitamin D measurement in a large population survey with statistical harmonization of assay variation to an international standard. The Journal of clinicalendocrinology and metabolism. 2007;92(12):4615-22.

8. Lechtermann C, Hauffa BP, Herrmann R, et al. Maternal vitamin $\mathrm{D}$ status in preeclampsia: seasonal changes are not influenced by placental gene expression of vitamin $\mathrm{D}$ metabolizing enzymes. Plos One. 2014;9(8):105558.

9. Arunabh S, Pollack S, Yeh J, Aloia JF. Body fat content and 25-hydroxyvitamin D levels in healthy women. The Journal of clinical endocrinology and metabolism. 2003;88(1):157-61.

10. De-Regil LM, Palacios C, Ansary A, Kulier R, Peña-Rosas JP. Vitamin D supplementation for women during pregnancy (Review). Cochrane Database of Systematic Reviews. 2012(2). 
11. Tsiaras WG, Weinstock MA. Factors influencing vitamin D status. Acta dermato-venereologica. 2011;91(2):115-24.

12. Mulligan ML, Felton SK, Riek AE, BernalMizrachi C. Implications of vitamin D deficiency in pregnancy and lactation. Am J Obstet Gynecol. 2010;202(5):1-9.

13. Sachan A, Gupta R, Das V, Agarwal A, Awasthi PK, Bhatia V. High prevalence of vitamin D deficiency among pregnant women and their newborns in northern India. The American Journal of Clinical Nutrition. 2005:1060-4.

14. Urrutia RP, Thorp JM. The Vitamin D Deficiency Pandemic: a Forgotten Hormone Important for Health. Public Health Reviews. 2010;32:267-83.

15. Haugen M, Brantsaeter A, Trogstad L, et al. Vitamin D supplementation and reduced risk of preeclampsia in nulliparous women. Epidemiology. 2009;20.
16. Wang A, Rana S, Karumanchi SA. Preeclampsia: The Role of Angiogenic Factors in Its Pathogenesis. Physiology. 2009;24:147-58.

17. Thorne-Lyman A, Fawzi WW. Vitamin D during pregnancy and maternal, neonatal and infant health outcomes: a systematic review and meta-analysis. Paediatric and perinatal epidemiology. 2012;26(1):75-90.

18. Wei S-Q, Qi H-P, Luo Z-C, Fraser W. Maternal vitamin $D$ status and risk of preeclampia: a systematic review and meta-analysis. American Journal of Obstetrics \& Gynecology. 2013:305.

19. Wei S, Bilodeau JF, Julien P, et al. Association of maternal vitamin $\mathrm{D}$ status and oxidative stress during pregnancy and risk of preeclampsia. American Journal of Obstetrics and Gynecology. 2014;210(1):169-70. 